\title{
The Principal's Leadership: How to Improve the Quality of Teaching and Learning Process in State Junior High School of Luwu
}

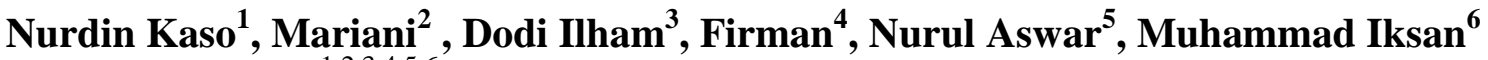 \\ 1,2,3,4,5,6 Institut Agama Islam Negeri (IAIN Palopo) \\ Email: dodi@iainpalopo.ac.id
}

\begin{abstract}
This study aims to determine the type of principal leadership in improving the quality of teaching and learning process, also supporting factors at State Junior High School 4 in Walenrang, Luwu. This research is a qualitative study using pedagogical, management, and psychological approaches. Instruments used observation, interviews, and documentation. This study indicates that the type of principal leadership in improving education quality at State Junior High School 4 Walenrang is a democratic type with personality, managerial, entrepreneurial, supervisory, and social competencies. The form of the principal's efforts to improve the quality of education at State Junior High School 4 Walenrang through 8 National Education Standards, namely content standards, process standards, graduate competency standards, standards for educators and education personnel, infrastructure standards, management standards, financing standards, and the assessment standards uses four approaches, namely: school review, benchmarking, quality assurance and quality control. Supporting factors in improving the quality of education at State Junior High School 4 Walenrang are teacher professionalism and a quality learning process, support from the government and local communities. The inhibiting factors are students' undisciplined behavior, lack of funds, and lack of IT tools
\end{abstract}

Keywords: Leadership, principals, teaching, learning

\section{INTRODUCTION}

The national education system provides directions and signposts in education, whether involving individuals, groups, community organizations, and society in general (Triwiyanto, 2015). Education is a continuous effort that aims to develop students' human potential in preparing them to face various challenges in life. Education is an effort to instill values in students to shape their character and personality. Education encourages students to embody these values into their daily behavior by the applicable curriculum. School is an organization for teaching and learning or a means of receiving and giving lessons. Schools are encouraged to pay greater attention to the spirit or spirit of education, the ability to adapt to vocational education, and careers. However, in essence, schools emphasize the intellectual, social, personality, or productive outcomes of school education (Setiyati, 2014; Nurhayati, 2019; Saudah, 2019; Setyowati, 2020). Studies of school principals' success in improving school institutions show that the principal is the one who determines the center point and rhythm of a school. As the top leader, the principal has the authority and power and an effective leadership type of organizing and developing his subordinates professionally. In carrying out his duties, the principal has a dual role as administrator, leader, and educational supervisor (Iskandar, 2017). Three managerial skills need to be mastered by principals, namely conceptual skills, human relations skills, and technical skills. These three managerial skills are needed to effectively carry out 
50 Jurnal Administrare: Jurnal Pemikiran Ilmiah dan Pendidikan Administrasi Perkantoran

Volume 8 Issue 1, January-June 2021. Pages 49-58

managerial tasks, although applying each of these skills depends on its level. (Wahyudi et al., 2020).

In implementing the school's vision, mission, and goals, the principal must have the right leadership strategy. The strategy is a "general program for the achievement of organizational goals in implementing the mission." The principal is a party who plays a very important role in driving school life, especially in improving school quality (Khairuddin, 2014). Therefore, school leadership policies play an important role in school management. Quality of education is a systemic and integrated activity by academic units or programs, administrators of academic units or programs, local governments, central government, and the community to increase the intelligence level of the nation's life through education. (Mulyasana, 2019). Increasing the quality of education or the quality of schools, each educational institution will strive to improve graduates' quality. It is impossible if an educational institution or school can produce quality graduates, but not through a quality education process. principals are required to be skilled at planning, organizing, mobilizing, and supervising activities in the fields of teaching, student affairs, finance, public relations, advice and infrastructure to improve the quality of education. (Syafaruddin, 2015). The urgency of improving the quality of teaching and learning process in schools includes all members of professional schools up to the stage of learning outcomes, attitudes, knowledge, and skills, can be fostered through various teaching and learning activities in schools, as well as coaching extracurricular activities as a vehicle to foster and develop an applicable educational curriculum. It is hoping that improve the quality of education in schools can be continued in the family and community environment. State Junior High School 4 Walenrang, as one of the educational institutions under the Education Office, is an institution that seeks to improve the quality of the teaching and learning process as an effort to realize character education. It includes building the character of students and school members based on the current educational curriculum.

\section{METHOD}

This research is field research using a qualitative approach (qualitative research) on the principal's leadership in improving the quality of education. Data in the form of words written, spoken, or behavior can be observed through interviews, observation, and documentation, which the researcher analyzes with qualitative methods.

This research's target is the principal's behavior or actions and policies in improving education quality. This study describes the type of principal leadership, the principal's efforts to improve the quality of education, and supporting and inhibiting factors in improving the quality of education in the researched school. The research subject is the principal as a leader who encourages, influences, motivates, directs, and fosters teachers to become professional teachers who can improve the quality of education in researched schools, teachers who are implementers in fostering, educating, training, and teaching students (Nurdin et al., 2019). Also, to form students' character based on the 2013 curriculum can produce quality students, students as recipients of subject matter who must have character and will become a quality generation, and society as a source of informants to prove the research's truth results. The object of the research was State Junior High School 4 Walenrang, Luwu. The object of this research discusses the principal's leadership in improving the quality of education. 
The data collection techniques were used through observation, interviews, and documentation. Observations are made by observing activities that have occurred or are currently ongoing regarding the principal's leadership. Interviews, conducted an in-depth interview, obtain in-depth information by asking respondents directly (Baderiah \& Ilham, 2019). Documentation is a technique in which data is obtained from documents in written objects such as notebooks, papers, regulations, diary bulletin, and more. The data collection carried out in this study is to obtain data related to the principal's leadership in improving the quality of education at State Junior High School 4 Walenrang and other data needed in this study. The data analysis technique used, namely obtained from the field, is recorded carefully and analyzed through data reduction. After data reduction, the next step is displaying the data, ending with drawing conclusions and verification.

\section{RESULT AND DISCUSSION}

\section{Leadership Type of the Principal of State Junior High School 4 Walenrang}

The results of observations, interviews, and documentation found that the leadership type of the principals of State Junior High School 4 Walenrang, which tends to apply a democratic type, can be seen from how the principal consults with his subordinates' problems and convey his ideas. The democratic type is based on the thought that an educational institution's activities can run smoothly and achieve predetermined goals if there is a problem and are decided with the principal and subordinates based on deliberation to reach a consensus.

However, certain situations and conditions require the principals of State Junior High School 4 Walenrang to be authoritarian; that is, the principal makes his own decisions because the decision or power rests entirely with the principal as the leader. The authoritarian type is based on the stance that all organization activities will run smoothly and achieve predetermined goals if the principal determines all decisions.

\section{Improving the Quality of the Teaching and Learning Process in State Junior High School 4 Walenrang}

The principal of State Junior High School 4 Walenrang efforts to improve the quality of education through the fulfillment of eight National Education Standards, especially in the fulfillment of infrastructure, determine academic and non-academic achievement standards through subject guidance and coaching or training for sports scouting talents. The State Junior High School 4 Walenrang principal always builds and communicates with the government, parents of students through school committees, and the community through a family approach. However, on the other hand, the reality in the field is that the national exam results of students in the last three years have decreased when compared to the previous year, only on nonacademic activities and increasing administration, this happens because internet access is not supported.

\section{Discussion}

\section{Principal Leadership Type}

The principal's leadership in improving the quality of education at State Junior High School 4 Walenrang is one of the school programs or plans discussed in teachers and staff meetings. Thus, it can be explained that the principal and all teachers at Walenrang State Junior 
High School collaborate in implementing programs to improve the quality of education in schools so that students have quality grades. It means that the cooperation can see the principal's success in improving the quality of education of all stakeholders in the school.

The State Junior High School 4 Walenrang principal is the front guard in carrying out his leadership. The final product of principal leadership is school performance that changes both teachers and students-change from not achieving high achievers. Meanwhile, the principal's leadership target in improving education quality starts with teachers, students and staff, and other resources. So, the principal's leadership in shaping the quality of the people he leads into a reliable generation will be a dignified nation's successor.

\section{School Principal Efforts to Improve Education Quality}

The improvement of the quality of education at State Junior High School 4 Walenrang cannot be separated from the principal's function as a leader who has full responsibility in managing the work program that has been jointly determined.

The principal as State Junior High School 4 Walenrang, already has a professional certificate through certification. Based on the decree for the division of duties, the principal has face-to-face 3 hours of learning a week. The subjects taken by the principal are by their areas of expertise, namely Physical Education, Sports, and Health.

The principal of State Junior High School 4 Walenrang performs its function of creating a school work program for the long, medium, and short term (1 year) that involves teachers, committees, supervisors, and local education leaders and community leaders. In managing educational personnel, the principal also carries out maintenance and professional development activities for teachers by facilitating and providing broad opportunities for teachers to carry out professional development through various educational and training activities, both in schools and outside of school.

The principal as State Junior High School 4 Walenrang, in carrying out his function as an administrator, in addition to working on student administration, personnel administration, teaching program administration, financial administration, community participation administration, equipment/goods administration, also requires teachers to make learning administration, student affairs, and class and regularly check teacher administration so that it is orderly and good.

To find out the extent to which teachers can carry out learning, the principal as State Junior High School 4 Walenrang periodically carries out supervision activities through class visits to observe the learning process directly, especially in the selection and use of methods, the media used, and student involvement in the learning process. From the results of this supervision, it can be seen that the weaknesses and strengths of the teacher in carrying out learning, the level of mastery of the competence of the teacher concerned, then strived for solutions, guidance, and certain follow-ups so that the teacher can correct existing deficiencies and maintain excellence in implementing learning. The implementation function is as the principal supervisor of State Junior High School 4 Walenrang in supervising the program and schedule well, using various supervision instruments and following up on the results of supervision, and reporting the results of supervision to exist stakeholders evaluation coaching.

Two types of principal leadership can improve the quality of education and at the same time encourage the improvement of teacher competence, namely the type of participatory 
leadership that is human-oriented and the type of democratic leadership that is task-oriented. To improve teacher competence, a principal can apply both leadership types appropriately and flexibly, according to existing conditions and needs. The teacher's work ethic is higher when led by the principal with the leadership-oriented to school conditions. The leadership of the principal affects teachers and student achievement. Leadership behavior positively affects student achievement to help teachers listen, support, and facilitate what teachers need to improve student achievement. The principal's effective leadership influences this

In this case, the principal of State Junior High School 4 Walenrang in carrying out its function as an innovator is very good because, during its leadership, the school has developed to procure civil servant teachers to overcome the shortage of teachers. The principal has also made several innovations in the classroom setting and is now conducting curriculum 2013 lessons.

The principal State Junior High School 4 Walenrang, always motivates teachers to improve their knowledge and competence. It is proven that all teachers have a bachelor's certificate, and many students excel academically and non-academically as well as students who have completed the exam successfully enter only high schools. Based on the results of interviews with several components of education at State Junior High School 4 Walenrang, he assessed that the principal could carry out his duties and functions well. Based on this, the authors get a positive note which can be concluded that: a principal can carry out his function as a leader either as an educator, manager, administrator, supervisor, leader, innovator, and motivator can run well and be successful, and it needs to be accompanied by determination, enthusiasm, self-ability, as well as courage to use strength, face obstacles, take advantage of opportunities, and face challenges, besides that, must have the ability to build relationships with stakeholders in the school environment.

The principal of State Junior High School 4 Walenrang, to improve the quality of education, the school carries out several activities that are curricular, co-curricular, and extracurricular; in addition to providing various needs in learning such as procuring computers, laptops, computer laboratories, these are intended to improve the quality of education. To improve the quality of education, a National Education Standard is needed, which becomes the basis for planning, implementing, and supervising education in realizing quality national education. There are also eight National Education Standards, namely:

\section{a. Content Standards}

Based on document 1 of the 2013 curriculum at State Junior High School 4 Walenrang was prepared to realize the vision of the school by accommodating the existing potential to improve the quality of academic units, both in academic and non-academic aspects, maintaining, developing regional culture, mastering science and technology based on faith and piety and with environmental insight and friendly to all students who refer to the vision and mission of the Luwu District Education Office.

\section{b. Process Standards}

The learning process at State Junior High School 4 Walenrang is carried out actively, innovatively, creatively, effectively, and fun, and provides sufficient space for the initiative, creativity, and independence according to the talents, interests, and physical and psychological development of students. The learning process standard must be a reference in carrying out the school's teaching and learning process activities. 


\section{Jurnal Administrare: Jurnal Pemikiran Ilmiah dan Pendidikan Administrasi Perkantoran Volume 8 Issue 1, January-June 2021. Pages 49-58}

\section{c. Graduates Competency Standards}

To determine the assessment results and determination of student graduation from the education unit, State Junior High School 4 Walenrang is guided by graduates' competency standards. Graduate competency standards include competencies for all subjects or groups of subjects. It is expected that graduates have character and abilities that can be developed in secondary schools.

\section{d. Teacher and Staff Standards}

The teacher must have academic qualifications and competencies as learning agents, be physically and mentally healthy, and have the ability to realize the goals of national education. At State Junior High School 4 Walenrang, there are educators with the highest educational qualifications of magister, and the lowest is bachelors. It means that the teaching staff in this school can master materials, manage teaching and learning programs, manage classes, use source media, master educational foundations, manage teaching and learning interactions, assess student achievement for teaching purposes, and organize school administration.

e. Facilities and Infrastructure Standards

Facilities and infrastructure standards in State Junior High School 4 Walenrang are based on national education standards relating to the minimum criteria regarding study rooms, places for sports, places of worship, libraries, laboratories, workshops, places for creation, and recreation, as well as other learning resources needed to support the learning process including the use of information and communication technology. The education unit has facilities that include furniture, educational equipment, educational media, books, and other learning resources, consumables, and other equipment needed to support an orderly and sustainable learning process and has infrastructure including land, classrooms, room for the leadership of the academic unit, room for educators, administration room, library room, laboratory room, workshop room, production unit room, canteen room, power and service installation, sports place, place of worship, playground, creative space, and other necessary spaces/places. The purpose of facilities and infrastructure standards in State Junior High School 4 Walenrang to support an orderly and continuous learning process. Means are anything that can be used as a means of achieving an objective or objective. The infrastructure makes it easier to distinguish between the two; facilities are more aimed at moving objects such as computers and machines, while infrastructure is more aimed at immovable objects such as buildings, space, and land.

\section{f. Management Standards}

The management of education at State Junior High School 4 Walenrang implements school-based management, demonstrated by independence, partnership, participation, openness, and accountability. Independence in the sense of maturity in carrying out all school programs, partnership means building cooperation with the community to build schools. School participation greatly determines the number of people who can receive education; openness can mean that all parties have the right to know all school activities, while accountability results from school performance and community satisfaction with schools' education services.

\section{g. Financing Standards}

Education financing is very influential in improving education quality because it is impossible to operate according to the goals formulated without an educational institution's cost. At State Junior High School 4 Walenrang, the funding comes from the School Operational Cost 
and the Free Education Fund. School operational costs are used to provide facilities and infrastructure, operational costs, and the cost of consumable educational materials or equipment. Financing is carried out based on technical guidelines for managing funds issued by the government every year to guide financing school operations. Education funding comes from the central government and local governments, and grants.

h. Assessment Standards

Assessment of learning outcomes by educators at State Junior High School 4 Walenrang is carried out in a planned and systematic manner to monitor the process of learning progress and improvement of learning outcomes through assignments and evaluation of learning outcomes, which include aspects of attitude, aspects of knowledge, and aspects of skills based on the 2013 curriculum that has been applied. Efforts to improve the quality of education carried out at State Junior High School 4 Walenrang cannot be separated from the principal's efforts as a leader who is responsible and has management skills in building good cooperation with all stakeholders in the school to achieve quality and quality national education goals. Improving the quality of education can run as expected if adequate funds support it. However, at State Junior High School 4 Walenrang, an obstacle to improving education quality is the lack of funds they have because funds only come from school operational assistance, which depends on students' number. Another obstacle experienced is the lack of state civil apparatus teachers. Improving education quality must be based on useful strategies as guidelines for implementation to be achieved properly. There are four approaches developed in education by several other countries, including school review, benchmarking, quality assurance, and quality control. The four techniques can be explained as follows:

1) School review

The process carried out by all stakeholders of State Junior High School 4 Walenrang is working with parents of students and professionals to evaluate and provide an assessment of school effectiveness and the quality of graduates. The principal as a leader carries out activities with a collaborative pattern to improve the quality of education, which greatly affects improving education quality. The achievement of the quality of education at State Junior High School 4 Walenrang, when viewed from graduates' quality, is by parents and students' expectations. Student achievement is very good both in the academic and non-academic fields, and it can be seen from the results of student achievement in the form of a certificate and certificate in the principal's room.

2) Benchmarking

The implementation of benchmarking results has implications for changes in performance. It can be seen from the teachers of State Junior High School 4 Walenrang, who have guided students who excel both academically and non-academically. Through a benchmarking strategy, educational institutions can easily obtain information to develop a school vision with insight.

3) Quality assurance

Quality in education is the main problem that will ensure schools' development in achieving status amid intense competition in education. Quality assurance is a way of producing that is free from defects and errors. For this reason, apart from considering 


\section{Jurnal Administrare: Jurnal Pemikiran Ilmiah dan Pendidikan Administrasi Perkantoran Volume 8 Issue 1, January-June 2021. Pages 49-58}

the quality of students, State Junior High School 4 Walenrang also needs to gain excellence amidst the many schools competing to show their quality.

4) Quality control

One of the eight national education standards, namely assessment standards, helps control education outcomes. The assessment standards suggest an assessment form that requires students to display attitudes, use the knowledge and skills obtained from learning to perform tasks in real situations, based on the 2013 curriculum used today

\section{CONCLUSION}

The principal's leadership type in improving the quality of education at State Junior High School 4 Walenrang applies a democratic type, but he can apply an authoritarian type in certain situations. Efforts to improve the quality of education at State Junior High School 4 Walenrang, namely by implementing PP No. 19 of 2005 on National Education Standards, and using four models developed by the world of education: school review, benchmarking, quality assurance, and quality control. It is an effort to improve the quality of education at State Junior High School 4 Walenrang.

The supporting and inhibiting factor in improving the quality of education, namely the supporting factor of school programs' sustainability to improve the quality of education at State Junior High School 4 Walenrang is teacher professionalism. This factor is a key in itself for school institutions' success in carrying out their programs, namely, support from students' government and parents. Establishing good communication between the school institution and students' parents is also the key to success and determines student achievement in carrying out learning activities. Then there is good cooperation between the principal and the teacher in supporting school activities. As for the inhibiting factor in improving the quality of education, namely the school environment's safety, in this case, the State Junior High School 4 Walenrang school has not been completely fenced. Other factors are lack of funds, lack of teachers with civil servant status, and inadequate IT access.

\section{REFERENCES}

Alarabiat, A., Soares, D., \& Estevez, E. (2020). Determinants of citizens' intention to engage in government-led electronic participation initiatives through Facebook. Government Information Quarterly, 101537. https://doi.org/https://doi.org/10.1016/j.giq.2020.101537

Amin, M., \& Nasharuddin, S. Z. (2013). Hospital service quality and its effects on patient satisfaction and behavioural intention. Clinical Governance. https://doi.org/10.1108/CGIJ05-2012-0016

Arhas, S. H., \& Suprianto, S. (2020). The Effectiveness of 6M Implementation at Artebo MSME. Jurnal Ad'ministrare, 6(2), 249-256.

Ayuningtyas, D., Fachry, A., Sutrisnawati, N. N. D., \& Munawaroh, S. (2020). Medical tourism as the improvement of public health service: A case study in Bali and West Nusa $\begin{array}{llll}\text { Tenggara. } & \text { Enfermería } & \text { Clínica, } & 30,\end{array}$ https://doi.org/https://doi.org/10.1016/j.enfcli.2020.06.029

Blondell, R. D., \& Azadfard, M. (2013). Hospital management. In Addressing Unhealthy 
Alcohol Use in Primary Care. https://doi.org/10.1007/978-1-4614-4779-5_18

Guptill, J. (2005). Knowledge management in health care. In Journal of Health Care Finance. https://doi.org/10.4018/978-1-61520-670-4.ch023

Handayani, P. W., Hidayanto, A. N., Pinem, A. A., Hapsari, I. C., Sandhyaduhita, P. I., \& Budi, I. (2017). Acceptance model of a Hospital Information System. International Journal of Medical Informatics. https://doi.org/10.1016/j.ijmedinf.2016.12.004

Hartwell, H. J., Shepherd, P. A., Edwards, J. S. A., \& Johns, N. (2016). What do patients value in the hospital meal experience? Appetite. https://doi.org/10.1016/j.appet.2015.09.023

Johns, N., Hartwell, H., \& Morgan, M. (2010). Improving the provision of meals in hospital. The patients' viewpoint. Appetite. https://doi.org/10.1016/j.appet.2009.10.005

Kalaja, R., Myshketa, R., \& Scalera, F. (2016). Service Quality Assessment in Health Care Sector: The Case of Durres Public Hospital. Procedia - Social and Behavioral Sciences. https://doi.org/10.1016/j.sbspro.2016.11.082

Langkai, J. E., Akib, H., Musa, I. C. T., \& Naharia, U. (2019). The Implementation of Environment-Based Program (PBL) To increase community welfare in Manado City. ODISHA JOURNAL OF SOCIAL SCIENCE, 19.

Rexhepi, L., \& Shrestha, P. (2011). Lean Service Implementation in Hospital. Rheumatology.

Rose, R. C., Uli, J., Abdul, M., \& Ng, K. L. (2004). Hospital service quality: A managerial challenge. International Journal of Health Care Quality Assurance. https://doi.org/10.1108/09526860410532784

Susanto, A., \& Meiryani. (2019). Database management system. International Journal of Scientific and Technology Research. https://doi.org/10.5120/179-310

Undang-Undang Nomor 23 Tahun 2014 tentang Pemerintahan Daerah, (2014).

Wenda, W. L., \& Akib, H. (2015). Pembangunan Ekonomi dalam Era Otonomi Daerah di Kabupaten Pegunungan Bintang, Indonesia. Jurnal Ilmiah Ilmu Administrasi Publik: Jurnal Pemikiran Dan Penelitian Administrasi Publik, 5(1), 43-51.

Zarei, A., Arab, M., Froushani, A. R., Rashidian, A., \& Tabatabaei, S. M. G. (2012). Service quality of private hospitals: The Iranian Patients' perspective. BMC Health Services Research. https://doi.org/10.1186/1472-6963-12-31 
58 | Jurnal Administrare: Jurnal Pemikiran Ilmiah dan Pendidikan Administrasi Perkantoran Volume 8 Issue 1, January-June 2021. Pages 49-58

This page is intentionally left blank 